\title{
THE ROLE OF FINANCE IN OUR LIVES
}

\author{
Shahbaz Khalid \\ MBA Executive, Virtual University of Pakistan
}

Article DOI: https://doi.org/10.36713/epra6706

\begin{abstract}
The article presents a comprehensive economics and financial analysis that plays a critical role in all areas of life. It plays an important role in individual resilience. This study includes financial and economical planning factors, revenue analysis, investment risk and financial forecasting. It includes budgeting, spending and saving. Healthy finances simply emphasize many of the goals of my life because healthy investments keep my daily stress level low, allow me to focus on doing other things, and open up opportunities to move forward. In other words, having the right level of financial success is one of the factors I measure in my life. How your financial skills help you understand how much you earn, what your monthly expenses are, and how it helps you budget for that income. The concept is that the sensitivity of investment to investment should be measured taking into account the amount of solid assets that can be used as collateral. High-level firms in the capital had high levels of investment sensitivity during the pre-crisis crisis, while post-crisis firms were less sensitive to cash flow when investing. Finance involves managing finances.

KEYWORDS: finance, importance of finance, learning finance, finance and accounting, life with finance, recognizing finance, roles of finance.
\end{abstract}

\section{INTRODUCTION Finance}

Finance is a study that finds out how money is made and used by individuals, corporations and organizations. It can mean thinking about how money can be managed to make profits. "To finance" is a verb that means to give capital to a company. Banking, leverage or debt, credit, financial markets, money, and investment-related practices all fall under the umbrella of finance. Finance also encompasses the control, growth, and study of assets, banking, credit, shares, properties, and liabilities that make up financial structures. Finance is a word for money and investment

You'll need money to start a company. It is evident that capital investment is needed to take the first step and launch your company. In addition, each single phase will include financial management as you move up the timeline, getting supplies, recruiting staff, marketing and testing management, growth, and research matters. It is possible to loosely categorize economics, public finance, corporate finance, and personal finance into three classes. Other specific concepts also exist, such as behavioral finance, which seeks to identify, for cognitive purposes (e.g., emotional, social, and psychological), the factors behind financial decisions. One of the most significant aspects of a corporation is financing. With enormous funds, daily cash flow and ongoing transactions, all the above turn is important to control and track. Financial management lets the company decides what to spend when to spend and what to spend in order to be precise.

\section{OBJECTIVES}

The aim of financial life planning is to help customers strike a balance between the two parties and thus allow them to live their lives to their full potential. Traditional financial planning focuses primarily on the quantitative aspect of budgeting, property planning, insurance policy, retirement benefits, taxation, etc. Financial life planning can be well described as 
Comprehensive process of financial planning that, when drawing up a strategy to help them handle

Financial life planning focuses on rising the wellbeing and desire of the individual to achieve their personal goals. This strategy helps the customer define their present conditions, goals, expectations and dreams from the beginning; helping the financial planner to develop a holistic financial plan that enables their customer to live their idea of a meaningful and enjoyable life.

Personal finance skills help you understand how much you make, what your monthly expenses are, and help you prepare for that money. Even the little things required, such as transport bills and groceries, as well as long-term objectives such as saving and investment, are influenced by personal finance. Finance, whether in a organization or in one's daily life, is often of great importance. This is important in the management of projects and business processes and also in the management of risks in everyday life. In various cases, such as buying a car or investing in gold, and so on, you will face financial risks. Finance, whether in a organization or in one's daily life, is often of great importance. Individuals face financial crises and need to manage financial risks on a regular basis. Since managing risks in business is important, managing risks in life is equally important as well. Danger is nothing but an unpredictable occurrence that could destroy your assets and it causes loss of financing because it is financial risk. Risk management includes a few steps: First, a risk must be identified, followed by risk assessment and risk reduction and control. This is important in the management of projects and business processes and also in the management of risks in everyday life. In different situations, such as buying a car or investing in gold, and so on, you can face financial risks. Let's take a look at the types of financial risks that can be seen in their daily lives before recognizing how to handle financial risks in everyday life.

Finance is every company's lifeline. Nevertheless, funds are often limited, like most other tools. Wants are still limitless, on the other hand. It is necessary, therefore, for a company to effectively manage its finances. In this article, as an introduction to financial management, we will look at the essence, scope, and importance, along with financial decisions and preparation, of financial management. Finance Management consists of planning, directing, tracking, coordinating and regulating an organization's monetary resources. It also means applying the concepts of management to an organization's financial assets, while also playing an important role in fiscal management.

An individual employed in managerial finance may be interested in the importance of the financial their finances, puts a client's interests first.

figures of a business calculated against different targets, such as internal goals and competitor figures. They will look at adjustments in asset flows to test for red flags that signify bill collection or bad debt issues, as well as evaluate working capital to predict potential cash flow issues.

Through the allocation of limited resources among competing market opportunities, sound financial management generates value and organizational capacity. It is an aid to business strategies' execution and tracking and helps achieve business goals.

Corporate finance is the field of finance that deals with business enterprises' monetary decisions and the instruments and research used to make those decisions. Maximizing shareholder value is the main objective of corporate finance. In theory, although it differs from management finance, which examines the financial decisions of all companies, rather than firms alone, the key principles in the study of corporate finance relate to the financial problems of all forms of companies.

It is necessary to break the discipline into decisions and strategies in the long and short term. Capital investments decisions are long-term decisions about the ventures receive investment, whether to fund the investment with equity or debt, and when to pay shareholders dividends, or whether to pay them. Shortterm decisions, on the other hand, discuss the shortterm balance of current assets and liabilities; the emphasis here is on cash management, inventories, short-term investing, and lending (such as credit terms extended to clients).

Investment banking is also synonymous with the words corporate finance and corporate financier. An investment bank's traditional job is to assess the financial needs of the business and raise the required form of capital that best suits those needs. The terms 'corporate finance' and 'corporate finance' can also be correlated with transactions in which capital is raised for the purpose of forming, expanding, increasing or acquiring companies.

\section{METHODOLOGY}

This article consists on secondary data sources. The systematic literature review methodology was used to identify accessible research studies in the finance discipline that used a hybrid process approach/methodological triangulation. I began by manually searching for finance-related mixed method research in leading multidisciplinary mixed method journals, such as Journal of Mixed Methods Research, International Journal of Qualitative Methods, International Journal of Multiple Approaches, Field 
Methods, Social Research Methodology, International Journal of Methodology (Quality and Quantity), and Sociological Methods.

Then I conducted a manual search in leading finance journals for accessible mixed methods reports: The Journal of Finance, Review of Finance, Review of Corporate Financial Studies, Journal of Corporate Finance, Journal of Banking and Finance, Journal of Scientific Finance, Accounting and Finance, Critical Finance Review, Journal of Financial Economics, International Review of Economics and Finance, Accounting and Finance, Critical Finance Review, Journal of Financial Economics, International Review of Economics and Finance, Accounting and Finance, Accounting and Finance, Critical Finance Review, Journal of Financial Economics, International Review of Economics and In this search, I only found one study that used mixed methods and was published in the Journal of Financial Economics.

Then I did a general search, finding key terms, published time periods, directories, and formulating discipline-specific inclusion criteria. Since I based on novel/recent contributions to mixed method studies to the discipline of finance, I performed this data base quest using the year 2000 as the starting point. Using the critical key terms of mixed procedure, triangulation, finance, accounting, economics, validity, and technique, I first screened the available related papers in Sage, Emerald, EBSCO host, Wiley, Science Direct, and a few other publishers.

I concentrated on scientific papers written in English-language peer-reviewed journals with full-text access, various article formats, and publications with key terms in the title, key words, or abstract.

In order to get a pleasant and detailed shape of the article, journals, books, stock exchanges, brokers and various sites were also considered as secondary sources available on the internet or in physical form to collect the raw data and information as much as possible on the topic chosen. It gives to an idea to shareholder.

For Example:-

\section{Case 1}

How to check return on assets ratio of three companies for three years?

Company A

Company B

Company $\mathrm{C}$

Formula:-

Return on Assets $=$

$\frac{\text { Net Income }}{\text { Total Assets }} \cdot \times 100$

Figures is in thousands dollars.

\begin{tabular}{|c|c|c|c|}
\hline Company Name & Year 2017 & Year 2018 & Year 2019 \\
\hline Company A & $\begin{array}{l}\$ 8,810 / \$ 331,259= \\
0.0266 \times 100=\mathbf{2 . 6 6 \%}\end{array}$ & $\begin{array}{l}\$ 78,516 / \quad \$ 276,498= \\
0.2840 \times 100=\mathbf{2 8 . 4 0 \%}\end{array}$ & $\begin{array}{l}\$ 303,691 / \quad \$ 374,490= \\
0.8110 \times 100=\mathbf{8 1 . 1 0} \%\end{array}$ \\
\hline Company B & $\begin{array}{l}\$ 980,056 / \quad \$ 318,874= \\
3.0735 \times 100=7.35 \%\end{array}$ & $\begin{array}{l}\$ 1,357,793 / \$ 372,819= \\
6.6420 \times 100=\mathbf{6 6 4 . 2 0 \%}\end{array}$ & $\begin{array}{l}\$ 1,728,135 / \$ 441,381= \\
3.9153 \times 100=\mathbf{3 9 1 . 5 3 \%}\end{array}$ \\
\hline Company C & $\begin{array}{l}\$ 1,476,364 / \$ 527,764= \\
2.7974 \times 100=\mathbf{2 7 9 . 7 4 \%}\end{array}$ & $\begin{array}{l}\$ 1,726,775 / \$ 629,710= \\
2.7422 \times 100=\mathbf{2 7 4 . 2 2 \%}\end{array}$ & $\begin{array}{l}\$ 2,267,966 / \$ 808,226= \\
2.8062 \times 100=\mathbf{2 8 0 . 6 2 \%}\end{array}$ \\
\hline
\end{tabular}




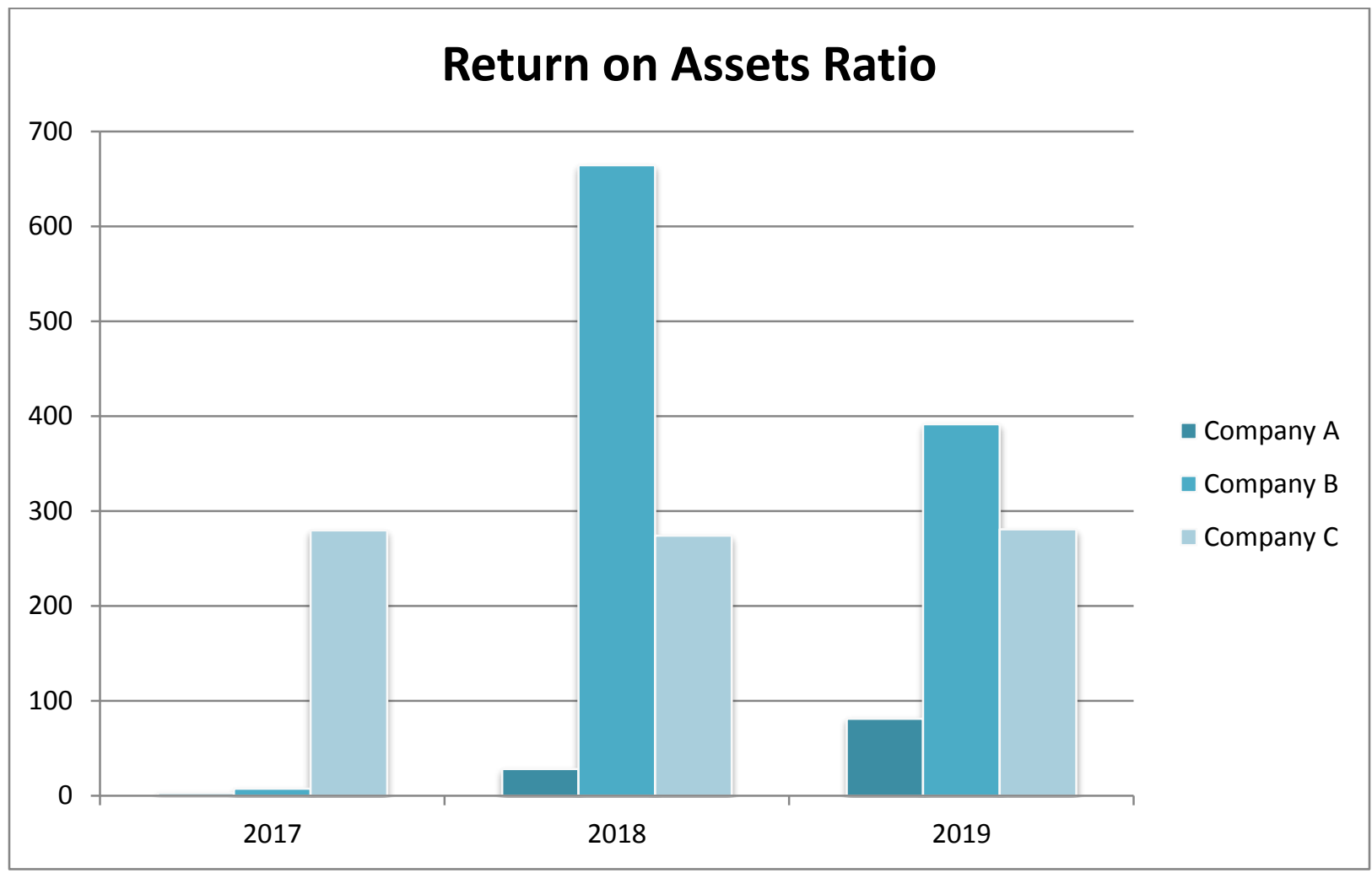

\section{RESULTS}

I found the results that finance is the main feature of life. Budgeting money is made easier by financial accounting. Budgeting aids you in deciding where your funds should be expended, how much should be saved, and how much should be invested depending on your revenue. Stick to your schedule, stop overspending, and bring money into investments, according to your lifestyle strategy. The result findings shows that how can we make our lives easy by using financial techniques. Finance is often important, whether in business or in one's personal life. It's critical to manage risks in industry, and it's also critical to manage risks in life. Risk is characterized as an unpredictable occurrence that can cause harm to the estate, and when it comes to financial losses, it results in financial loss. Personal finance is concerned with meeting the needs of an entity or a person, and it includes both long and short-term financial objectives. This is all about finance, whether you have enough funds to cover your vital monthly expenses or you intend to prepare for retirement. Being financially literate allows an individual to differentiate between financial choices that will benefit their financial future and those that will harm it. Getting a financial plan would encourage you to fulfill your short and long-term needs while remaining within your income limits.
The finance sector comprises three major subcategories: personal finance, corporate finance, and public (government) finance, though individuals, corporations, and government agencies all need financing to function.

\section{SUGGESTION}

- It is suggested that maximize income resources and minimize the expanses.

- Make planning about saving.

- Pay yourself what you're worth and waste less money than you make.

- Make a budget and stick to it.

- Make a contribution to a retirement account.

- Get rid of your credit card balance.

- Create a budget and stick to it.

- Make the Best of The Career Benefits.

- Examine the insurance policies.

- Make a change of your will. Keep accurate records.

- Take control of your financial future.

- Make an emergency fund for yourself.

- Keep an eye on your expenses.

- Keep tabs on your net worth. 


\section{CONCLUSION}

It is concluded that finance is the part of life. Without finance it is difficult to manage income and expenses. It gives the solution related to investment and budgeting. It tell us that how to make budgets and planning about future. It give an overview that where to invest money for better return on investment. By the using finance ratio formulas we can get the future figures related to income and expenses. It tells to shareholders that which company is better for investment. Finance helps to every person who is connected with social and economical life.

\section{REFRENCES}

1. Adam, T. \& Goyal, V.K. 2008. The investment opportunity set and its proxy variables. The Journal of Financial Research, 31(1): 41-63.

2. Akinboade, O.A. \& Makina, D. 2006. Financial sector development in South Africa, 1970-2002. Studies in Economics and Econometrics, 30(1): 101-127.

3. Al Najjar,B. 2011. Empirical modeling of capital structure: Jordanian evidence. Journal of Emerging Market Finance. 10(1): 1-19.

4. Ameer, R. 2003. Financial liberalisation and capital structure dynamics in developing countries: evidence from emerging markets of South East Asia. ABS Finance Working Paper, No. 01/2003.

5. Anderson, T.W. \& Hsiao, C. 1982. „Formulation and estimation of dynamic models using panel data. Journal of Econometrics, 18(1): 47-82.

6. Antoniou, A., Guney, Y \& Paudyal, K. 2006. The determinants of debt maturity structure, evidence from France, Germany and UK. European Financial Management, 12(2): 161- 194. 